\title{
Virtual Museum Space as the Innovative Tool for the Student Research Practice
}

\author{
https://doi.org/10.3991/ijet.v16i14.22975 \\ Viktoriia Tserklevych $(\bowtie)$ \\ Khmelnytskyi Cooperative Trade and Economic Institute, \\ Khmelnytskyi, Ukraine \\ w. zerklevitch@gmail.com \\ Olha Prokopenko \\ Collegium Mazovia Innovative University, Siedlce, Poland \\ Olena Goncharova \\ Kyiv National University of Culture and Arts, Kyiv, Ukraine \\ Inna Horbenko \\ Hryhorii Skovoroda University, Pereiaslav, Ukraine \\ Oksana Fedorenko \\ Borys Grinchenko Kyiv University, Kyiv, Ukraine \\ Yaroslavna Romanyuk \\ Sumy State University, Sumy, Ukraine
}

\begin{abstract}
The article presents the results of theoretical substantiation and practical approbation of modern possibilities for applying the visual teaching method. The EU countries' educational experience on modern ways of working with museum expositions to form economic thinking is studied. The content of the two-stage pedagogical experiment is characterized. At the first stage, the possibilities of using educational excursions through museums and historically significant territories of cities as a studying method are researched. The authors' pedagogical product is presented - regional-themed tours on economics' history. Using Ukrainian museums' online resources (virtual tours, virtual exhibitions) has been developed and tested at the second stage. The thematic catalog of Ukrainian museums' online resources for broad research practices has been created. The presented innovative tool has shown its effectiveness in improving the educational process quality, forming information and media literacy, and applying inclusive education. This pedagogical tool is essential in the context of the COVID-19 pandemic and for students with disabilities.
\end{abstract}

Keywords - Visual method, virtual museum, student research practice, innovative educational tool, inclusive education, students with disabilities 


\section{Introduction}

Training of innovative type specialists is determined by the Law of Ukraine "On Higher Education" [1] as the primary aim of scientific, creative, qualitative, and innovative higher education institutions. It requires the approbation and implementation of high-quality, innovative educational technologies [2]. The proposed argument is consolidated with the interpretation of the higher education quality [3], which states that the characteristics of the specialist-graduate and the factors of the formation of this result depend on education, content, methodology, organization and technology of learning [4]. Information technologies hold absolute superiority in the 21st century [5], [6], [7]. The ability to work critically with mega information databases (information literacy) and media literacy are the necessary foundations for the formation of professional competence of the specialist and the critical component of the teacher's information culture.

Another trend in the organization of the qualitative educational process in the first quarter of the 21 st century is its visualization, which acquires special significance in presenting fundamental socio-humanitarian and economy-wide disciplines, including the "History of Economics and Economic Thought". This discipline's main task is the formation of economic thinking, the ability to establish cause-and-effect relationships and patterns of the historical process, to predict the economic future consistent with Immanuel Kant's thesis of "managing the future from the past."

The importance of using the information and digital resources in the organization of the qualitative educational process, modern opportunities for visualization of processes and phenomena of historical past and present, is confirmed by annual (20142018) monitoring of the opinion of the recipients of educational services of Ukoopspilka on effective teaching practices. Thus, prioritizing two characteristics of the teacher - "effective pedagogical techniques" and "individual pedagogical skills" undergraduates $(68 \%)$ choose the first one.

Undergraduate students, performing the ranking of the characteristics of teaching skills, gave priority to the following: the teacher's ability to prove the need to study the discipline for future professional activities (89\%); synchronicity of mastering the discipline and the development of relevant competencies (72\%); information and media literacy of the teacher $(68 \%)$.

To search for effective techniques for teaching economics students' fundamental discipline, the authors implemented the pedagogical experiment on studying the didactic possibilities of using virtual museums' resources, virtual tours as the platform for student research practices. This experiment was carried out on the example of the discipline "History of Economics and Economic Thought". The development of creative pedagogical technology is substantiated by: 
- The priority of the competence approach in the training of specialists [1], [8], [9].

- The tasks of the modern historical science: understanding the history as a process of "alive" research, expanding the possibilities of work with the primary sources due to the digitization, the ability to the authorial interpretation of historical events in the search for the truth [10].

- The change of the paradigm of the traditional museum in the 21st century [11] and universities' integration in innovation networks [12].

The article aims:

- To substantiate the didactic practicality of using the visual (museum-excursion) method as an innovative teaching tool in the teaching of historical disciplines in the context of new quality.

- To characterize the resources of domestic virtual museums, virtual tours as a platform for student research practices in the "History of Economics and Economic Thought"; to demonstrate the example of research work with the exposition of the virtual museum.

- To prove that work in the virtual museum space is competency-oriented, multidisciplinary educational practice, an effective form of organizing creative and independent students' work.

As a result of the experiment, it also became clear that this form of education is suitable for students with disabilities. Later, the innovative teaching method was widely used due to the COVID-19 pandemic, becoming an excellent teaching solution.

For the research practice material, such as the services for virtual tours as Google Expeditions, Google Cultural Institute, materials of archival collections of historical materials Archive Exhibitions were used. Materials of the Google project "Digital Transformation of Ukraine", Google virtual tour "Authentic Ukraine", 3D tours through museums in Street View mode at Google Maps were used directly in the pedagogical experiment. Expositions of virtual museums were realized within the projects "Ukraine Incognita", "Museum portal" and others.

The experiment provided for learning the traditional possibilities of using the excursion method and analysis of museum exhibits in the teaching of the discipline "History of Economics and Economic Thought" at the first stage; work with resources of virtual museums and virtual excursions with the organization of independent work of students at the second stage. Its chronological limits were 2014-2018. 3720 students from the authors' universities were involved.

\section{Research Methods and Models}

The theoretical and methodological basis of the study is an interdisciplinary approach that integrates the strategies of different fields of scientific knowledge: pedagogy, history, economics, creativeness, information technology and systems. When studying the culturological and educational phenomenon of the virtual museum, we 
were based on the theories of post-industrial and information societies [13], [14], [15]; theories of functioning of the Internet as an information channel and its social functions [16], [17], [18] and E-learning [19], [20], [21].

Thanks to empirical research methods, Ukrainian virtual museums' preliminary information was consolidated. Those were chosen based on which research practices on the discipline could be conducted. The direct observation of collections and expositions of virtual museums was applied. The empirical material of search queries in information and search systems was collected. Questionnaires were conducted to find the effective synergy of traditional and innovative teaching methods in students' opinions during 2014-2018.

The two-stage pedagogical experiment was implemented. It was based on synergetics principles for combining classical and innovative visual teaching methods. The ranking of priority competencies proved the effectiveness of students' independent work at the platforms of virtual museums. The research results' scientific substantiation was carried out based on a narrative approach.

\section{Results and Discussion}

\subsection{Background}

In the 17th century, Komenskyi formulated and substantiated the principle of priority of visibility in education, explaining it as follows: “... everything that can only be imagined for perception with the help of senses, namely: the visible - for the perception by eyesight, what is heard - by hearing, what smells - by smell, what tastes - by taste, the available to touch - by touch. Suppose several senses can perceive the certain objects at once, let several senses perceive them at once" [22].

The opinion of the patriarch of the study of visual sources of modern times Panofsky is consistent with this view established in didactics: "only what is comprehended through the mediation of the visual representation, is endowed with the property of reality" [23, p.14]. In 1953, the founder of the school of "Annals" Febvre, considering on the range of sources of the historian, noted that it could be anything (primarily visual), that, belonging to the human, depended on him, served him, expressed him, pointed to his presence, activity, tastes and ways of life. The determined approach allows us to interpret the visual images as a particular type of text that requires "deciphering" within the discourse of its origin.

Modern researchers believe that society has entered a new era of history, in which the visual becomes the central aspect of socio-economic life. The art critic Gombrich [24] is one of the first who notes the comprehensiveness of visuality: "we live in the visual time. We are "thrown" with pictures from morning till night. Opening the newspaper at breakfast, we see photos of men and women, look away from the newspaper and see an image on the package of oatmeal..."

Lesch argues that there is a replacement of literary perception in modern society by visual images: "We live in the world, where images as the main cultural forms, displace texts" [25]. Global medialization, digitization and visualization of the world 
created the conditions for the "return of the image, symbolism, the imaginary to the forefront" (La Rocca) and caused the tendency to move from the text to the symbol. Thus, a group of researchers headed by Mitchell [26] substantiated the definition "visual turn" ("pictorial turn") as evidence of visuality in the quality of the primary source of information. Today the visual culture extends its expansion to all social life spheres but needs a thorough study. The visual culture is endowed with forming a new social subject in society, where the Internet and the media's visual field forms a person's identity [27], [28].

Simultaneously, in the Ukrainian historical and pedagogical sciences, the tradition of using visual sources to study the socio-economic, economic content of specific historical periods is unformed. It is evidenced by the lack of publications of Ukrainian researchers on educational opportunities of the virtual museum space, virtual tours, digitized exhibits and exhibitions. Among the works that characterize the transformation of the mission of the world and Ukrainian museums following the demands of the information society, it is necessary to note the study by Chernenko [27], in which the evolution of virtual museums is observed: from the interactive exhibition of the Leicestershire Museum (UK, 1983), the first museum network information site based on the French MINITEL system, Jonathan Bowen's virtual library "Museum Pages" (Oxford University, 1994) to the creation of the International Council of Museums (ICOM) website (1995) and digital versions of thousands of museums around the world during the last years. Analyzing Ukrainian museums' virtual space, Chernenko (2004) concludes that "in general, we are only at the beginning of the process of modernization of the museum sector of the state". Nesgovorova [27], Vyatkina [29], Smirnova [30, p. 24-26] did typology and classification of virtual museums. They made the clear semantic distinction between real museums' sites, where video tours, 3D tours, 3D panoramas, 360-degree photo panoramas, digitized museum collections and virtual museums that do not have real (material) analogs. The change in museums' socio-cultural and educational function is reflected in the works of the manager of the British Museum N. McGregor: "in the future, museums should function as information publishers or television companies" [31].

Determination of the limits of applying the resources of virtual museums directs us to study the educational trends of the information society [32, pp. 126-127], in particular, the didactic possibilities of the virtual excursion, new formats of museum pedagogy in the space of virtual museum [33], use of resources of virtual museums and virtual tours in work of general education schools [34], [35]; technological aspects of creating virtual museums [36, pp. 83-85]. The individual research is currently devoted to the experience of using the virtual museum space, the possibilities of virtual excursions in high school, among which the scientific generalizations of Maksimova [37] are distinguished.

Developing pedagogical technology for working with visual sources of historical information at the first and second stages of the pedagogical experiment, we were guided by professional standards and regulations of professional ethics of the American Historical Association [10], priority competencies of the New Ukrainian School [36], critical competencies of specialists until 2020 according to the recommendations of the World Economic Forum in Davos [39]. 
In the study, the virtual museum is considered as:

1. The information resource (website, web page) created through computer technology, which is a digital version of the objects of tangible and intangible heritage in cyberspace [29, p. 24-26]; computer-generated model of the museum, which exists in the cyberspace and "reproduces the exhibits and expositions of the real museum: from art objects and historical artifacts to virtual collections and family relics" [40].

2. "Multimedia phenomenon that provides the possibility of interactive cooperation" [40, p. 188], [41, p. 3940] is characterized by the possibility of feedback from site visitors, reproduction of museum objects, the presence of three-dimensional museum exhibits that "create the possibility of the virtual journey through the exhibition and its independent modeling" [40, p. 48]

3. The cost-effective model of museum resources.

Authors interpret a virtual tour as an organizational form of learning that differs from a real tour by a virtual display of real objects to create the conditions for selfobservation and collection of necessary facts. Its advantages are accessibility (resource, economic), the possibility of the second review, visibility [42].

\subsection{The main results}

The information age's personality is at the epicenter of global information flows every minute. Its life success depends directly on how the cognitive dissonance is resolved: whether a person becomes informationally and technologically dependent, whether the development of his ability to analyze, "filter" the information flow, use limitless possibilities of technology is transformed into his or her unlimited opportunities for development and improvement.

The specificity of the traditional study of the discipline "History of Economics and Economic Thought" and all historical disciplines lies in the fact that teachers, and accordingly students, use text documents in the quality of the primary source. However, the "visual turn" of the middle of the 20th century caused the radical restructuring of historical cognition technologies. In the quality of visual sources, the teachers of the 20th century [42] determined: material monuments of the past; documentary images and illustrations, including photo portraits, documentary films and photos; works of historical painting, portraits and feature films; caricatures and symbolic images; schematic plans and historical maps; diagrams, graphs, schemes. The presented list is relevant in the 21 st century, but it can be considered real and in a digital-virtual format.

The place where all these objects are consolidated is the museum. "The museum is a place where knowledge is constructed and acquired" [44]. The quintessence of the visual method in studying historical disciplines is a tour. In the practical and pragmatic sense, the tour provides for visiting objects and places, acquaintance with the museum exhibition or sights of a particular city or region with the guide's help. The tour's pedagogical task is its construction based on tourists' maximum activity and independent mental activity, forming their skills of independent observation and anal- 
ysis of visual information and visual impressions. Technological tools that provide the implementation of the requirements for excursion services are 1) logical skills: analysis, comparison, synthesis, abstraction, generalization; 2) methods of demonstration preliminary review, panoramic display, visual analysis, reconstruction, localization of events; 3) narration - excursion reference, description, description of the object, explanation, reportage, commenting, citation, cento [45].

Classically, the tour as a qualitative method of studying is used when teaching such disciplines as "History of Ukraine", "History of Ukrainian Culture", "Culturology". The use of this method during the process of teaching "History of Economics and Economic Thought" is complicated by the need for significant research and methodological work to prepare specific thematic tours aimed at the analytical work with museum exhibits, complex studies of preserved architectonics of cities and the ability to characterize the essential features of the business, socio-economic development of a particular historical period based on studying the artifacts of material culture.

The innovativeness of historical and economic excursions is evidenced by the lack of scientific publications on the experience of implementing this technology. The first-year students' survey results also confirmed it (3 720 respondents from 2014 to 2018), Fig. 1.

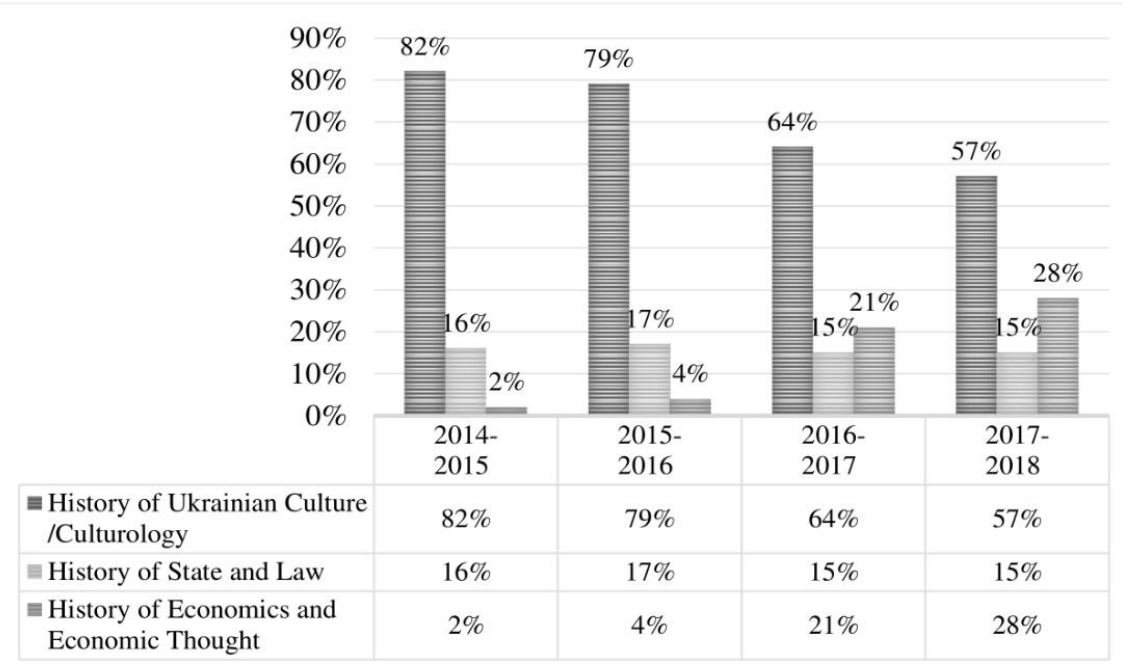

Fig. 1. The results of the survey on the appropriateness of using the tour as a form of educational activity

The increase in the number of respondents, who consider the excursion method to be appropriate, is explained by the communication of first-year students with seniors who have such an opinion. The study of EU countries' experience on educational trends on the use of visual aids in school education became the decisive argument in favor of the pedagogical experiment. Thus, in historical education in Ireland at the 
second level of the national education system, the pupils of 12-15 years age learn to construct historical knowledge with archeology, source studies, and art. Simultaneously, the learning process itself is based on the analysis of city planning, fortification, sacral architectural monuments and works of art. French history textbooks for middle school pupils are a short text that occupies $1 / 3$ of the educational area, directs the pupil to the analytical study of illustrations, documents, and other textbook components (2/3). In Edinburgh's National Museum of Scotland, a series of tasks was developed for each thematic excursion for schoolchildren to review and study the relevant exhibition. Lessons are differentiated by difficulty levels and can be offered in different combinations according to the pupil's academic progress.

The example of the research task: imagine yourself as the wife of a wealthy burgher who will invite future business partners from the Netherlands to your house. Your family is very proud of your wealth and tries to impress guests with your home improvement. Take a look at the exhibits and choose five items for your home to help you complete the task. Justify your choice. Draw these things: decorations made of silver, glass, overseas souvenirs and more.

This strategy of working with museum exhibits turns a museum (classical, virtual, historical blocks of cities, open-air museums) into a space for communication and education. Here, "the visitor not only encounters the problems of modern society seen through the prism of history and memory but also can respond and react to what is exposed to it. Museums should not limit themselves by turning interactivity into a set of questions and answers; they should use the exhibition to provoke and involve visitors in dialogue" [46].

Therefore, let us characterize the content of the first stage of the pedagogical experiment on the possibilities of applying the visual method through museums and excursions in the teaching of "History of Economics and Economic Thought" (Table 1) shortly.

The shortcomings found during the implementation of the first stage of the experiment became the motivation for searching for the new qualitative forms of implementing visual methods in teaching. It became possible due to virtual museums, virtual tours and virtual city tours. Surveys conducted among first-year students from 2016 to 2018 (780 people) showed the de facto lack ( $8 \%$ of respondents) of experience with virtual tours and platforms of virtual museums (Fig. 2). 
The study tour within the educational process is:

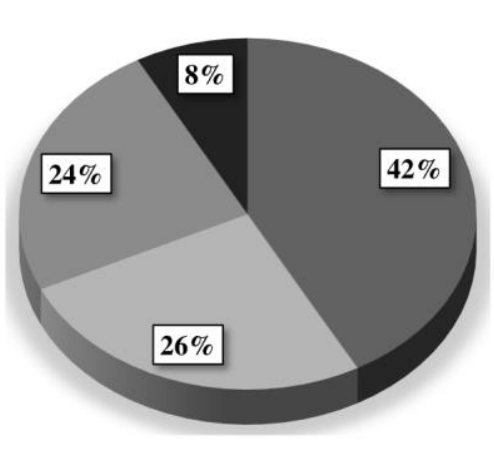
a) tour through the city, enterprise, museum, etc. on the topic (topics), determined by the program of the discipline;
B) excursion, on the results of which it is required to prepare a report in accordance with the determined form beforehand;
E) excursion, which provides for the preliminary preparation according to the tasks defined by the teacher and analytical and research work on the results;
D) virtual tour or tour through the virtual museum.

Fig. 2. Results of the survey of students of understanding the content of the study tour within the educational process

Table 1. The content of the creative pedagogical experiment on modern possibilities of applying the visual method (educational excursions) in teaching

"History of Economics and Economic Thought"

\begin{tabular}{|c|c|c|c|c|}
\hline Years & Work content & Received results & Advantages & $\begin{array}{c}\text { Disad- } \\
\text { vantages }\end{array}$ \\
\hline $\begin{array}{l}2013- \\
2014\end{array}$ & $\begin{array}{l}\text { Comparison of the world } \\
\text { and domestic contexts of } \\
\text { economic history and } \\
\text { economic thought. For- } \\
\text { mation of the Ukrainian } \\
\text { museums' database, the } \\
\text { expositions of which allow } \\
\text { to carry out research work } \\
\text { on economic history. } \\
\text { Development of thematic } \\
\text { tourist routes through the } \\
\text { region according to the } \\
\text { discipline's content. }\end{array}$ & $\begin{array}{l}\text { Creation of the meaningful canvas of } \\
\text { regional economic history (Podillya } \\
\text { and South-Eastern Volyn); formation } \\
\text { of the database of materials to develop } \\
\text { texts of excursions, methodical devel- } \\
\text { opments of seminars and tasks for } \\
\text { independent work of students. }\end{array}$ & \multirow{2}{*}{$\begin{array}{l}\text { Maximum use of } \\
\text { the visual method } \\
\text { in the study of } \\
\text { HEET discipline, } \\
\text { multidisciplinary, } \\
\text { research nature of } \\
\text { teaching, ensuring } \\
\text { the perception of } \\
\text { economic history } \\
\text { from the stand- } \\
\text { point of global and } \\
\text { regional approach- } \\
\text { es, drawing out the } \\
\text { educational pro- } \\
\text { cess from the } \\
\text { exclusively "class- } \\
\text { room" format. } \\
\text { Possibility of } \\
\text { constant contact } \\
\text { with scientists- } \\
\text { museum workers, } \\
\text { receiving individ- } \\
\text { ual expert consul- } \\
\text { tations on the } \\
\text { preparation of } \\
\text { materials on } \\
\text { regional economic } \\
\text { history. } \\
\end{array}$} & \multirow{2}{*}{$\begin{array}{l}\text { Resource } \\
\text { of time } \\
\text { condi- } \\
\text { tioned by } \\
\text { the re- } \\
\text { search } \\
\text { objects' } \\
\text { territorial } \\
\text { remote- } \\
\text { ness; } \\
\text { conduct- } \\
\text { ing the } \\
\text { over- } \\
\text { whelming } \\
\text { majority } \\
\text { of excur- } \\
\text { sions in } \\
\text { out-of- } \\
\text { lesson } \\
\text { time, } \\
\text { material } \\
\text { resources } \\
\text { related to } \\
\text { the com- } \\
\text { pensation } \\
\text { of costs } \\
\text { for trans- } \\
\text { portation } \\
\text { and } \\
\text { museum } \\
\text { services. }\end{array}$} \\
\hline $\begin{array}{c}2014- \\
2016\end{array}$ & $\begin{array}{l}\text { Approbation and im- } \\
\text { provement of thematic } \\
\text { tourist routes through the } \\
\text { region and Ukraine accord- } \\
\text { ing to the content of the } \\
\text { discipline HEET. } \\
\text { Development of research } \\
\text { tasks, which allows as- } \\
\text { sessing the level of compe- } \\
\text { tencies formation resulting } \\
\text { from studying the disci- } \\
\text { pline. }\end{array}$ & $\begin{array}{l}\text { Creation of the author's pedagogical } \\
\text { product - thematic excursions on } \\
\text { HEET through regional history exam- } \\
\text { ples. For example, seminars: "Eco- } \\
\text { nomic life of the medieval city: archi- } \\
\text { tecture and museums of Kamianets- } \\
\text { Podilskyi" (Old Town, museums of } \\
\text { Kamyanets-Podilskyi); "Two dimen- } \\
\text { sions of the socio-economic reality of } \\
\text { the Soviet Union of the first half of the } \\
\text { 20th century (Famine-Genocide } \\
\text { Museum in State Historical and Cul- } \\
\text { tural Conservation Area "Mezhybizh", } \\
\text { Museum by M. Ostrovskyj, Shepetiv- } \\
\text { ka). Scientific and methodological } \\
\text { generalization of the first stage of the } \\
\text { experiment [47]. }\end{array}$ & & \\
\hline
\end{tabular}


Empirical studies on the number of search queries by the definitions of "virtual museum", "virtual tour" in the Google network gave the following results (Table 2).

Table 2. Quantitative differences of search queries by definitions of "virtual museum", "virtual tour"

\begin{tabular}{|l|c|c|c|c|}
\hline \multicolumn{1}{|c|}{ Definition } & $\begin{array}{c}\text { A search query in } \\
\text { Ukrainian, } \\
\text { number, thous. }\end{array}$ & $\begin{array}{c}\text { A search query in } \\
\text { Russian, } \\
\text { number, thous. }\end{array}$ & $\begin{array}{c}\text { A search query in } \\
\text { English, } \\
\text { number, thous. }\end{array}$ & $\begin{array}{c}\text { Correlation between } \\
\text { the number of } \\
\text { search queries }\end{array}$ \\
\hline Virtual museum & 38,4 & 939 & 2770 & $1: 24: 72$ \\
\hline Virtual excursion & 106 & 1120 & 66000 & $1: 11: 623$ \\
\hline
\end{tabular}

The development of didactic possibilities of using the visual method has demonstrated a sufficient list of works on the valuable results of its application in various fields of humanities and no research on the use of virtual museums and virtual tours in teaching disciplines of historical and economic content.

Thus, the second stage of the creative pedagogical experiment implementation (2016-2018) provided for the solution of the following tasks:

- The formation of the database of virtual tours, Ukrainian virtual museums, the expositions of which allows to carry out the researches on "History of Economics and Economic Thought" (according to the topics of the discipline);

- The creation and approbation of research tasks on the discipline, which are based on work with collections of museum exhibits of virtual museums or visual information of virtual tours through cities;

- The development of the system of tasks with methodical recommendations for students' independent work, built on analyzing virtual museums' expositions or visual information of 3-D tours.

It is expedient to characterize domestic virtual museums and virtual tours from an information and technical perspective. The overwhelming majority of Ukrainian "virtual museums" is a collection of several Web pages hosted at one or more Webservers. These pages contain collections of panoramic photographs of exhibits. In the Ukrainian information space, the most widespread is the simplest type of virtual museum - "flat". Modern requirements provide for the three-dimensionality of virtual museums and additional functions. One can view the museum exhibit as close as possible and, if necessary, save the image.

A virtual tour is a combination of panoramic photos (spherical or cylindrical). The transition from one panorama to another is carried out through the active zone (socalled anchor points or transition points), placed directly on the images, with the tour plan. All this can be supplemented by foreground sound and background music, and if necessary, the stock photos, videos, flash clips, tour plans, explanations, contact information and more.

Forming the base of virtual museums and excursions, following the issues of "History of Economics and Economic Thought", we used the world services for virtual tours: Google Expeditions; Culture Academy (Google Cultural Institute), in particular, the materials of the project of archival collections of historical materials Archive 
Exhibitions; materials of the Google project "Digital Transformation of Ukraine", the campaign of Google "Authentic Ukraine", 3D tours of museums in Street View mode at Google Maps [48].

The independent research subject studied available Ukrainian virtual museums' available resources, presented in the projects "Museum Portal", "Ukraine Incognita". The conducted study showed that the resource of virtual museums' high-quality content for student research practices in economic history is limited. Consolidated information on the resources of virtual museums of Ukraine allowed the distribution of research sites following the discipline's subject (Table 3).

The presented virtual museums and Google art collections have simple functionality - free movement in the halls, the possibility to study in detail, enlarging the exhibit, and the ability to move through the museum's galleries by hovering the cursor. Currently, Ukrainian virtual museums do not perform detailed information about the exhibition's subject by hovering the cursor, which distinguishes them from similar museums in the EU and the US.

The standard scheme of interaction of the student-excursionist with the virtual museum is shown in Fig. 3.

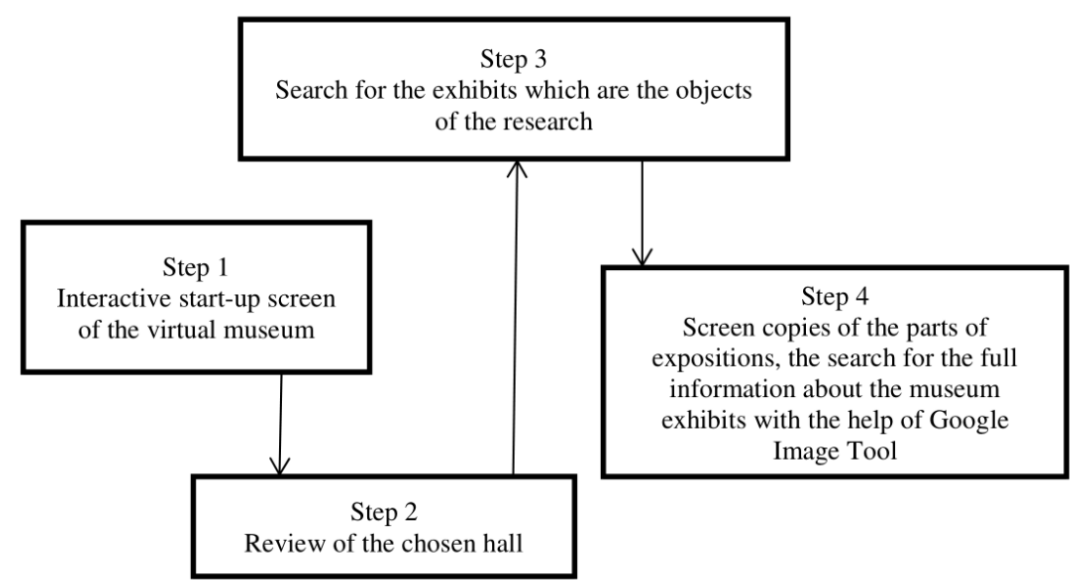

Fig. 3. The standard scheme of interaction of the student-excursionist with an exposition of the virtual museum 
Table 3. Online resources of Ukrainian museums for creative research practices on the discipline "History of Economics and Economic Thought"

\begin{tabular}{|c|c|c|c|}
\hline $\begin{array}{l}\text { Discipline topics: the } \\
\text { world and Ukrainian } \\
\text { contexts }\end{array}$ & Virtual excursion & Resource & Project \\
\hline $\begin{array}{l}\text { The economy of primi- } \\
\text { tive society and its } \\
\text { evolution at the stage of } \\
\text { early civilizations } \\
\text { The economy of early } \\
\text { civilizations on the } \\
\text { territory of modern } \\
\text { Ukrainian lands } \\
\end{array}$ & $\begin{array}{l}\text { Historical and Archaeological } \\
\text { Museum "Ancient Aratta - } \\
\text { Ukraine", Trypillya village } \\
\text { Virtual tour of the Dneprope- } \\
\text { trovsk National Historical } \\
\text { Museum named for Ya- } \\
\text { vornytskyj (Hall 1. Ancient } \\
\text { history of the region) } \\
\end{array}$ & \begin{tabular}{|l|} 
http://incognita.day.kiev.ua \\
Imuseums.html \\
http://incognita.day.kiev.ua \\
lirtualna-ekskursiya- \\
dnipropetrovskym- \\
natsionalnym-istorychnym- \\
muzeiem- \\
yavornytskogo.html \\
\end{tabular} & $\begin{array}{l}\text { Ukraine Incognita, } \\
\text { the project of the } \\
\text { newspaper "Day" }\end{array}$ \\
\hline \multirow{2}{*}{$\begin{array}{l}\text { Formation of European } \\
\text { civilization. } \\
\text { Ancient Greek civiliza- } \\
\text { tion and its impact on the } \\
\text { European world }\end{array}$} & $\begin{array}{l}\text { National historical and arche- } \\
\text { ological conservation area } \\
\text { "Olviya" }\end{array}$ & \begin{tabular}{|l|} 
https://museum- \\
por- \\
tal.com/ua/museum/natsion \\
alniy-istpryko- \\
arheologichniy-zaovidnyk- \\
olviya \\
\end{tabular} & Museum portal \\
\hline & $\begin{array}{l}\text { Expositions of the ancient } \\
\text { history of Ukraine, early Iron } \\
\text { Age, early Slavs and Kyivan } \\
\text { Rus of the National Museum } \\
\text { of History of Ukraine }\end{array}$ & $\begin{array}{l}\text { https://www.nmiu.com.ua/e } \\
\text { xposition }\end{array}$ & \multirow{2}{*}{$\begin{array}{l}\text { National Museum of } \\
\text { Ukrainian History } \\
\text { with support of Sky } \\
\text { Soft Technology }\end{array}$} \\
\hline $\begin{array}{l}\text { Economics and econom- } \\
\text { ic thought of medieval } \\
\text { civilizations. } \\
\text { Genesis of Ukrainian } \\
\text { civilization in the Middle } \\
\text { Ages }\end{array}$ & $\begin{array}{l}\text { Expositions of late medieval } \\
\text { and early modern history of } \\
\text { Ukraine of the National } \\
\text { Museum of History of } \\
\text { Ukraine }\end{array}$ & http://virtual.nmiu.com.ua/ & \\
\hline \multirow{6}{*}{$\begin{array}{l}\text { Formation of precondi- } \\
\text { tions of market economy } \\
\text { in the countries of the } \\
\text { European civilization } \\
\text { The economy of Ukrain- } \\
\text { ian lands in Modern } \\
\text { Times }\end{array}$} & $\begin{array}{l}\text { Virtual tour in Dubenskyj } \\
\text { Castle }\end{array}$ & \begin{tabular}{|l|} 
http://incognita.day.kiev.ua \\
/virtualna-ekskursiya- \\
dubenskim-zamkom.html \\
\end{tabular} & \multirow{5}{*}{$\begin{array}{l}\text { Ukraine Incognita, } \\
\text { the project of the } \\
\text { newspaper "Day" }\end{array}$} \\
\hline & $\begin{array}{l}\text { Virtual tour in Ostrozkyj } \\
\text { Castle }\end{array}$ & \begin{tabular}{|l|} 
http://incognita.day.kiev.ua \\
/virtualna-ekskursiya- \\
ostrozkim-zamkom.html \\
\end{tabular} & \\
\hline & $\begin{array}{l}\text { Virtual tour in Hetmanship } \\
\text { Museum }\end{array}$ & $\begin{array}{l}\text { http://incognita.day.kiev.ua } \\
\text { /muzej-hetmanstva.html } \\
\end{array}$ & \\
\hline & $\begin{array}{l}\text { Kyryl Razumovskyj Palace in } \\
\text { Baturin }\end{array}$ & $\begin{array}{l}\text { http://incognita.day.kiev.ua } \\
\text { palacz-kirila- } \\
\text { rozumovskogo-u- } \\
\text { baturini.html }\end{array}$ & \\
\hline & $\begin{array}{l}\text { Virtual tour of Glass Museum } \\
\text { in Lviv }\end{array}$ & $\begin{array}{l}\text { http://incognita.day.kiev.ua } \\
\text { muzej-skla-u-lvovi.html } \\
\end{array}$ & \\
\hline & \begin{tabular}{|l|} 
Center for Ethnology \\
"Mamaeva Sloboda" (Kyiv); \\
Khortytsya Nature Reserve \\
(Zaporizhzhya); residence of \\
Bohdan Khmelnytskyj in \\
Chyhyryn
\end{tabular} & $\begin{array}{l}\text { Site "Museums of the sky" } \\
\text { http://museums.authenticuk } \\
\text { raine.com.ua/ua/ }\end{array}$ & $\begin{array}{l}3 \text { D-tours in muse- } \\
\text { ums in Street View } \\
\text { Mode Google Maps }\end{array}$ \\
\hline $\begin{array}{l}\text { The market economy of } \\
\text { European civilization in } \\
\text { the period of monopolis- } \\
\text { tic competition. } \\
\text { Peculiarities of market }\end{array}$ & $\begin{array}{l}\text { Virtual tour of the Dneprope- } \\
\text { trovsk National Historical } \\
\text { Museum named for D.I. } \\
\text { Yavornytskyj (Hall 4. Kateri- } \\
\text { naslavschchina in the second }\end{array}$ & $\frac{\text { http://incognita.day.kiev.ua }}{\text { /muzej-hrushevskoho.html }}$ & $\begin{array}{l}\text { Ukraine Incognita, } \\
\text { the project of the } \\
\text { newspaper "Day" }\end{array}$ \\
\hline
\end{tabular}




\begin{tabular}{|c|c|c|c|}
\hline \multirow{4}{*}{$\begin{array}{l}\text { economy development } \\
\text { and main directions of } \\
\text { economic thought in } \\
\text { Ukraine (second half of } \\
\text { the XIXth-beginning of } \\
\text { the XXth century) }\end{array}$} & $\begin{array}{l}\text { half of the XIXth-XXth } \\
\text { centuries) }\end{array}$ & & \\
\hline & $\begin{array}{l}\text { Virtual tour of the Museum of } \\
\text { History and Culture of the } \\
\text { Jews of Bukovina }\end{array}$ & $\begin{array}{l}\text { http://incognita.day.kiev.ua } \\
\text { /virtualna-ekskursiya- } \\
\text { muzeyem-istoriyi-ta- } \\
\text { kulturi-yevreyiv- } \\
\text { bukovini.html } \\
\end{array}$ & \\
\hline & $\begin{array}{l}\text { Virtual tour of the Historical } \\
\text { and Memorial Museum of M. } \\
\text { Hrushevskyj }\end{array}$ & $\begin{array}{l}\text { http://incognita.day.kiev.ua } \\
\text { muzej-hrushevskoho.html } \\
\end{array}$ & \\
\hline & $\begin{array}{l}\text { Virtual tour of the Vyacheslav } \\
\text { Lypynskyj Memorial Museum } \\
\text { in Zaturtsi village }\end{array}$ & $\begin{array}{l}\text { http://incognita.day.kiev.ua } \\
\text { lmuzej-lipinskogo.html }\end{array}$ & \\
\hline \multirow{6}{*}{$\begin{array}{l}\text { The economic develop- } \\
\text { ment of Ukraine under } \\
\text { the conditions of the } \\
\text { Soviet economic system } \\
\text { and its interpretation in } \\
\text { economic thought }\end{array}$} & $\begin{array}{l}\text { Stepan Bendera Museum in } \\
\text { London }\end{array}$ & $\begin{array}{l}\text { http://incognita.day.kiev.ua } \\
\text { lmuzej-stepana-banderi-u- } \\
\text { londoni.html } \\
\end{array}$ & \multirow{4}{*}{$\begin{array}{l}\text { Ukraine Incognita, } \\
\text { the project of the } \\
\text { newspaper "Day" }\end{array}$} \\
\hline & $\begin{array}{l}\text { Virtual tour of the National } \\
\text { Museum "Chornobyl" }\end{array}$ & $\begin{array}{l}\text { http://chornobylmuseum.ki } \\
\text { ev.ua/uk/?optio }\end{array}$ & \\
\hline & $\begin{array}{l}\text { Virtual tour of the National } \\
\text { Military and History Museum } \\
\text { of Ukraine }\end{array}$ & $\begin{array}{l}\text { http://incognita.day.kiev.ua } \\
\text { /virtualna-ekskursiya- } \\
\text { naczionalnim-vijskovo- } \\
\text { istorichnim-muzeyem- } \\
\text { ukrayini.html } \\
\end{array}$ & \\
\hline & $\begin{array}{l}\text { Memorial Museum "Prison in } \\
\text { Lontskyj” in Lviv }\end{array}$ & $\begin{array}{l}\text { http://incognita.day.kiev.ua } \\
\text { /muzej-memorial-tyurma- } \\
\text { na-lonczkogo-u-lvovi.html } \\
\end{array}$ & \\
\hline & $\begin{array}{l}\text { Cosmonautics Museum } \\
\text { named for S. Korolyov }\end{array}$ & http://cosmosmuseum.info/ & $\begin{array}{l}\text { The project of the } \\
\text { Museum of Cosmo- } \\
\text { nautics named for S. } \\
\text { Korolyova of Zhyto- } \\
\text { myr Regional State } \\
\text { Administration }\end{array}$ \\
\hline & $\begin{array}{l}\text { Exhibits "Ukraine as a part of } \\
\text { other states. From the New } \\
\text { Economic Policy to Stalin's } \\
\text { totalitarianism", "Ukraine as } \\
\text { part of the USSR: from the } \\
\text { Thaw period to the Recon- } \\
\text { struction period" of the Na- } \\
\text { tional Museum of History of } \\
\text { Ukraine }\end{array}$ & http://virtual.nmiu.com.ua/ & $\begin{array}{l}\text { National Museum of } \\
\text { Ukrainian History } \\
\text { with support of Sky } \\
\text { Soft Technology }\end{array}$ \\
\hline $\begin{array}{l}\text { Market transformations } \\
\text { in Ukraine }\end{array}$ & $\begin{array}{l}\text { Money Museum of National } \\
\text { Bank of Ukraine }\end{array}$ & https://bank.gov.ua/3dtour/ & \begin{tabular}{|l|} 
Information and \\
educational project of \\
the National Bank of \\
Ukraine
\end{tabular} \\
\hline
\end{tabular}

Source: Author's research using [49], [50]

An example of a task for students' independent work with the virtual museum's exposition is presented in Table 4. 
Table 4. The example of the task for independent work of students with the exposition of a virtual museum

\begin{tabular}{|c|c|c|}
\hline $\begin{array}{l}\text { The content of the } \\
\text { discipline topic }\end{array}$ & $\begin{array}{c}\text { Resources for virtual } \\
\text { excursions }\end{array}$ & $\begin{array}{c}\text { The task for the independent } \\
\text { work of the students }\end{array}$ \\
\hline $\begin{array}{l}\text { The topic of the lecture: } \\
\text { "Formation of precondi- } \\
\text { tions of market economy } \\
\text { in the countries of the } \\
\text { European civilization (16 } \\
\text { - 17th centuries)". } \\
\text { The topic of the seminar: } \\
\text { "Formation of industrial } \\
\text { civilization in Europe and } \\
\text { the economy of Ukrainian } \\
\text { areas". } \\
\text { The topic of the inde- } \\
\text { pendent work of students: } \\
\text { "Economic, political and } \\
\text { educational activities of } \\
\text { the Ostroh Princes as the } \\
\text { regional reflection of the } \\
\text { formation of the precondi- } \\
\text { tions of the market econ- } \\
\text { omy in the countries of } \\
\text { European civilization" }\end{array}$ & $\begin{array}{l}\text { 1) Virtual tour of Dubna Castle } \\
\text { http://incognita.day.kiev.ua/mu } \\
\text { seums/dubno/ } \\
\text { 2) Virtual tour of Ostoh Castle } \\
\text { http://incognita.day.kiev.ua/mu } \\
\text { seums/ostrohcastle } \\
\text { 3) Ukrainian Military History } \\
\text { http://www.ucrainarma.org/no } \\
\text { vini/vystavka-zbroji-v- } \\
\text { nmiu.html } \\
\text { 4) Malchenko O.E. Artillery } \\
\text { arsenal of the Kyiv fortress in } \\
\text { the second half of the XVIInd } \\
\text { century: formation, structure, } \\
\text { functions. Dissertation of } \\
\begin{array}{l}\text { Historical Sciences Doctor } \\
\text { http://shron1.chtyvo.org.ua/Ma }\end{array} \\
\text { lchen- } \\
\text { ko Oleh/Artyleriiskyi arsenal } \\
\text { Kyivskoi fortetsi u druhii_p } \\
\text { olo- } \\
\text { vyni XVII st formuvannia st } \\
\text { ruktura funktsii.pdf } \\
\end{array}$ & $\begin{array}{l}\text { The example of the research situation. The } \\
\text { presence of weapons is the primary security } \\
\text { condition in the late Middle Ages and Modern } \\
\text { Times on the Polish-Lithuanian Common- } \\
\text { wealth's borderlands. In one of the castles } \\
\text { owned by Princes, there were } 73 \text { guns ("Regis- } \\
\text { ter of Treasures of the Castle of the Princes of } \\
\text { Ostroh" (1616)). Find out the history of manu- } \\
\text { facturing, evaluate the current value of one of } \\
\text { the guns of the Princes of Ostroh. Determine } \\
\text { which of Ostroh Princes' residences is men- } \\
\text { tioned in the "Register"? } \\
\text { Methodical instructions for the task. From the } \\
\text { "Ukraine Incognita" website, follow the link to } \\
\text { virtual museums' resources (sources 1, 2). } \\
\text { Make screenshots of photo panoramas of parts } \\
\text { of the exposition, where guns are presented as } \\
\text { exhibits. Calculate the number of guns in the } \\
\text { expositions of Ostroh and Dubno castles. } \\
\text { Use the Google Image Search Tool (imag- } \\
\text { es.google.com) to identify the selected exhibits } \\
\text { (copy the image URL) and check if the exhibit's } \\
\text { guns are listed in the Princes of Ostroh Castle } \\
\text { Treasure Register. } \\
\text { Please choose one of the exhibits and prepare a } \\
\text { research essay on the place and time of manu- } \\
\text { facturing the gun, } \\
\text { its estimated cost at the time of manufacturing } \\
\text { and the } 21 \text { st century (resources } 3,4 \text { ). }\end{array}$ \\
\hline
\end{tabular}

The effectiveness of the organization of students' independent work, built on research practices with the usage of virtual museums' resources, is confirmed by the results of control surveys (Fig. 4, Fig. 5). 


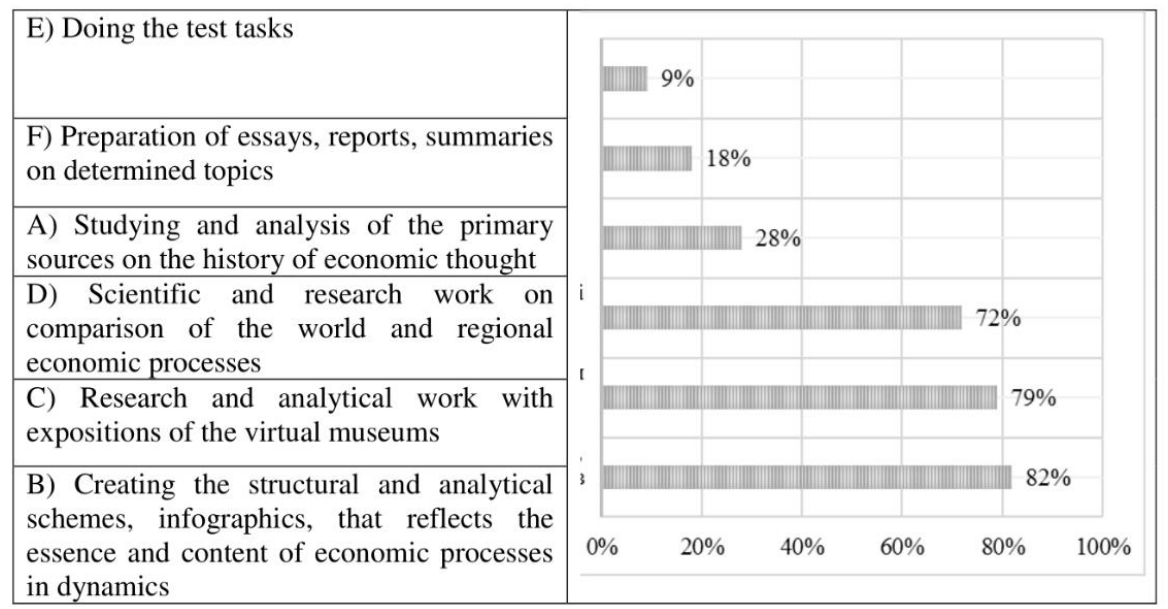

Fig. 4. Results of ranking the priority forms of activity for the development of economic thinking by students when performing tasks of independent work

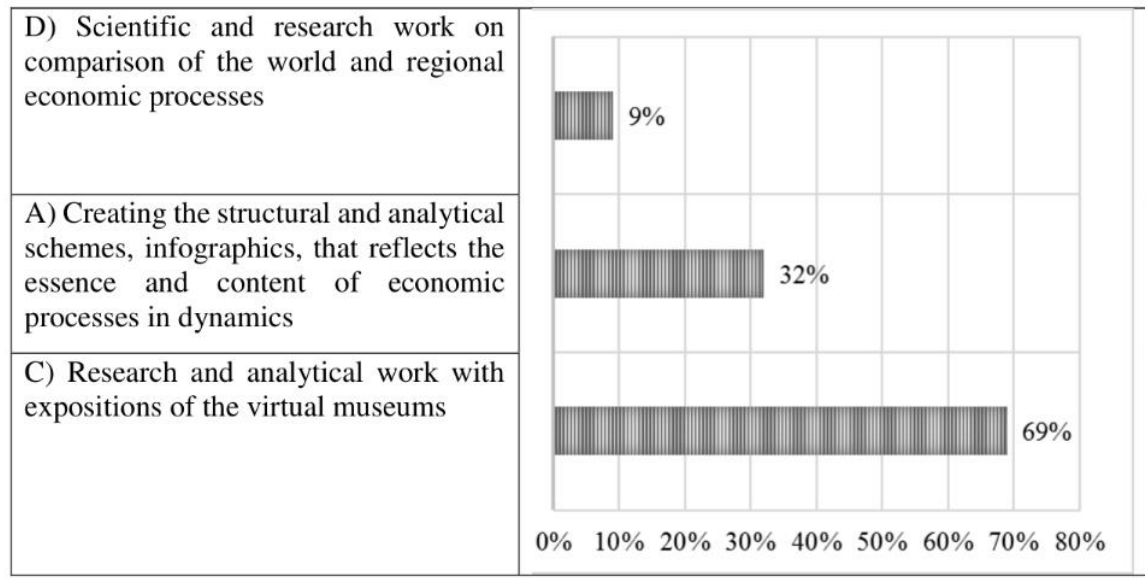

Fig. 5. Results of ranking the forms of work by students which demand the multicompetent approach in solving the set tasks to the greatest extent based on creativity

It is noteworthy that when answering the question: "From the list of competencies necessary for the specialist, choose three, at the formation of which work in virtual museums was aimed", the most significant number of elections is taken by comprehensive problem solving (88\%), critical thinking (76\%), the flexibility of mind (32\%), which corresponds to the top-1, top-2, top-10 competencies needed by professionals by 2020 [38] that confirms the effectiveness of the presented pedagogical technology. 


\section{Conclusion}

The fundamental study of modern possibilities of applying the visual method, particularly the online resources of Ukrainian museums in the teaching of "History of Economics and Economic Thought", lets us summarize the following.

The "visual turn", as the dominant method in Western European and American research practices of the 20-21st centuries, requires a departure from the traditional paradigm of attitude to texts as the primary source used by historians. The visual sources that are various objects (exhibits, artifacts), which characterize history's dynamics, including economic ones, are consolidated in museums. Without rejecting the traditional museum tour as an effective way to understand economic history, it is appropriate to use online museums and exhibitions of virtual museums - an organic component of the information society.

Virtualization, digitization of museum objects, expositions, museum space, in general, is a component of the new reality of different quality, the space of life of the modern personality and specialist. Questionnaires conducted at the end of the second stage of the experiment showed that $79 \%$ of students believed that research and analytical work with virtual museum exhibits helped develop economic thinking. According to the results of ranking the forms of work conducted by students that most require a multi-competent approach in solving tasks, the work in the virtual museum space took the first place (69\%). The answers to the questions about specialists' top competencies until 2020, determined by Davos' economic forum, seem convincing for proving the effectiveness of work with the expositions of virtual museums. Students believe that research work in the online museum space contributes to forming such competencies to solve problems, critical thinking, and flexibility comprehensively. Also, the proposed form of education is right for organizing inclusive education.

We consider studying the possibilities of using the world museums' online resources to master economic history, the history of the world culture, and art history being a prospect for further research. It is expedient to develop methodical materials on seminars and students' independent work, built based on the excursion method. The study and implementation of educational ideas and practical experience of EU and US universities on pedagogical technologies in working with virtual museums' resources are especially relevant.

\section{$5 \quad$ References}

[1] The Verkhovna Rada of Ukraine. (2019). Law of Ukraine No. 1556-VII "On Higher Education" (Jul. 04, 01). Available: https://zakon.rada.gov.ua/laws/show/1556-18 . Accessed on: Feb. 10. 2019.

[2] Soeiro, A. (2020). Quality of Continuing Engineering Education: DAETE and EFQM. Quality of Continuing Engineering Education: DAETE and EFQM, 13(4), pp. 57-67. https://doi.org/10.3991/ijac.v13i4.16811

[3] World Declaration on Higher Education for the Twenty-First Century: Vision and Action. (1998). http://www.un-documents.net/wdhe21c.htm 
[4] Gryshchenko, I. (2012). The economic nature of education production. Economics and Sociology, 5(2), pp. 50-57.

[5] Olshanska, O. et al. (2019). Building a competency model student training. International Journal of Engineering and Advanced Technology, 8(6), pp. 2689-2695.

[6] Robul, Y. et al. (2020). Cyber sales as the latest tool for optimizing an enterprise strategy. International Journal of Scientific and Technology Research, 9(2), pp. 5264-5268. http://www.ijstr.org/final-print/feb2020/Cyber-Sales-As-The-Latest-Tool-For-OptimizingAn-Enterprise-Strategy.pdf

[7] Shkarlet, S. et al. (2020). Transformation of the Paradigm of the Economic Entities Development in Digital Economy. WSEAS Transactions on Environment and Development, 16, pp. 413-422. https://doi.org/10.37394/232015.2020.16.41

[8] Dzwigol, H., Dzwigol-Barosz, M., Miskiewicz, R., \& Kwilinski, A. (2020). Manager Competency Assessment Model in the Conditions of Industry 4.0. Entrepreneurship and Sustainability Issues, 7(4), 2630-2644. https://doi.org/10.9770/jesi.2020.7.4(5)

[9] Prokopenko, O. et al. (2020). Competence approach in future specialist skills development. International Journal of Management. 11(4), Article number IJM_11_04_062, pp. 645-65.

[10] Standards of professional activity. (2019). Regulations of official professional ethics. American Historical Association - about the core values and practices of the profession of historian. Available: http://gefter.ru/archive/9373/ . Accessed on: Feb. 19, 2019.

[11] Tymofeeva, L. S. (2010). Transformation of the educational function of the museum: a historical retrospective (XVII - early XX century), Muzeinoe obrazovanye y obrazovanye $\mathrm{v}$ muzee, 1, p. 82-88. Available: http://history.spbu.ru/userfi les/VM_Timofeeva.pdf . Accessed on: Feb. 19. 2019.

[12] Prokopenko, O. et al. (2018). Information and communication technologies support for the participation of universities in innovation networks (comparative study). Innovative Marketing. 14 (3), pp 17-29. https://doi.org/10.21511/im.14(3).2018.03

[13] Bell, D. (1999). The upcoming post-industrial society. The experience of the social forecasting. M.: Academia.

[14] Toffler, E. (1999). The third wave. M.: LTD "Company "Publishing house AST", 1999.

[15] Eco U. (1998). From the Internet to Gutenberg. The new literary review, 32. pp. 5-14.

[16] Bauman, Z. (2020). Globalization. Columbia University Press.

[17] Castells, M. (2020). Information epoch. Economy, society and culture. M.: Higher Economy School.

[18] Hu Ji. (2021). Teaching Evaluation System by use of Machine Learning and Artificial Intelligence Methods. International Journal of Emerging Technologies in Learning, 16(5), pp. 87-101. https://doi.org/10.3991/ijet.v16i05.20299

[19] Kwilinski, A. et al. (2020). Information Support of the Entrepreneurship Model Complex with the Application of Cloud Technologies. Journal of Entrepreneurship Education, 23(SI1), 1-9. Retrieved from https://www.abacademies.org/articles/Information-supportof-the-entrepreneurship-1528-2651-23-S1-557.pdf

[20] Ouadoud, M. et al. (2021). Overview of E-learning Platforms for Teaching and Learning. International Journal of Recent Contributions from Engineering, Science \& IT, 9(1), pp. 50-70. https://doi.org/10.3991/ijes.v9i1.21111

[21] Bondar, I., Gumenyuk, T., Horban, Y., Karakoz, O., \& Chaikovska, O. (2021). Distance Elearning in the system of professional development of corporation managers: Challenges of COVID-19. Journal of Education and e-Learning Research, 7(4), pp. 456-463. https://doi.org/10.20448/journal.509.2020.74.456.463

[22] Komenskyi, Ya. A. et al. (1989). Pedagogical heritage. Moscow, Russia: Pedahohika. 
[23] Narskiy, V. et al. (2008). The obvious story. Problems of the visual history of Russia of the twentieth century. Chelyabinsk, Russia: Kamennyiy poyas.

[24] Gombrih, E. (1998). Art history. Moscow, Russia: AST.

[25] Emmison, M., \& Smith, P. (2012). Researching the Visual, Introducing Qualitative Methods. London: Sage Publications.

[26] Mitchell, W.J.T. (1995). What is Visual Culture? Meaning in the Visual Arts: Views from the Outside, ed. I. Lavin, Princeton, NJ: Institute for Advanced Study, pp. 207-217.

[27] Chernenko, O. (2004). World and Ukrainian Museums in the Information and Computer Society, Istoryko-heohrafichni doslidzhennia v Ukraini, 7, pp. 146-160.

[28] Bondar, I., Humeniuk, T., Batchenko, L., Horban, Y., \& Honchar, L. (2021). State Regulation of the Development of Educational and Scientific Process in Higer Education Institutions. Journal of Management Information and Decision Science, 24(2), pp. 1-10.

[29] Vyatkina, Yu. D. (2012). Virtual museum as a PR tool, Chelovek v mire kulturyi, 4.

[30] Smyrnova, T. (2010). Virtual Museum in the modern cultural and informational space, Muzei, 8, pp. 24-26.

[31] Higgins, C. (2019). Museums' future lies on the Internet, say Serota and MacGregor. Available: http://www.guardian.co.uk/artanddesign/2009/jul/08/museums-future-liesonline?INTCMP=SRCH . Accessed on: Mart 01, 2019.

[32] Ivanova, E. O., \& Osmolovskaya, I. M. (2011). Learning Theory in the Information Society. Moscow, Russia: Prosveschenie,

[33] Kuchuryn, V. (2014). Virtual museum pedagogy: modern opportunities and prospects, Saint-Petersburg, Russia: Nauchno-metodicheskiy tsentr Krasnogvardeyskogo rayona.

[34] Podliniaieva, O. (2019). Virtual excursion in the work of the teacher. Available: http://spec.vntu.edu.ua/conf/pdf/conf_402-415.pdf . Accessed on: Mart 01, 2019.

[35] Aleksandrova, E. V. (2010). Virtual excursion as one of the effective forms of organization of the educational process, Istoriia Ukrainy, 10, p. 22-24.

[36] Kondratovych, O., \& Marchyk, T. (2014). Virtual museum, museum room: opportunities, stages of creation, prospects, Sovremennoe obrazovanie Vitebschinyi, 4(6), pp. 83-85.

[37] Maksimova, T. (2012). Virtual museums: approaches to typology, Vestnik MGUKI, 4(48), p. 188.

[38] Deputies have changed the list of key competencies. (2019). Available: http://nus.org.ua/ news/deputaty-zminyly-perelik-klyuchovyh-kompetentnostej-nush/ . Accessed on: Mart $01,2019$.

[39] TOP-10 competencies of most professions and distance learning. (2019). Available: http://i-go-go.com.ua/top-10-kompetencij-bolshinstva-professij-i-distancionnogoobucheniya/ . Accessed on: Mart 01, 2019.

[40] Kaulen, M. E. et al. (2009). Dictionary of current museum terms, Muzei, 5. p. 48.

[41] Bashynska I. et al. (2019). Game Risk Management Methods for Investment Portfolio Optimization, International Journal of Recent Technology and Engineering, 8 (2), pp. 39403943 https://doi.org/10.35940/ijrte.b1729.078219

[42] Tanashchuk, E.A. et al. (2018). Theoretical and methodical principles of capital structure management in the innovation activity of telecommunication operators. Journal of Automation and Information Sciences, 50(3), pp. 71-84. https://doi.org/10.1615/jautomat infscien.v50.i3.60

[43] Vagin, A. A. (1968). The methodology of history teaching in secondary school. M., 431 p.

[44] Bartolomé, O. (2006). El museo como espacio de legitimación social, Museology - Field of Knowledge. Museology and History, 35, pp. 130-138.

[45] Belkhamza, Z., \& Abdullah, M. M. B. (2019). Trainee Characteristics and Organizational Environment for Enhancing Individual Performance in e-Learning Involvement. Interna- 
tional Journal of Web-Based and Teaching Technologies, 14 (2), pp. 88-101. https://doi.org/10.4018/ijwltt.2019040106

[46] Mensh, P. (2019). Convergence and divergence. Museums of science and technology in historical perspective. Available: http://www.mus.ahk.nl/03_onderzoek_ontwikkeling/03 publicaties/pvm bibliografie.js . Accessed on: Mart 01, 2019.

[47] Tserklevych, V. S. (2017). Modern possibilities of using the visual method in teaching history of economics, Vyshcha shkola. Naukovo-praktychne vydannia MON Ukrainy, 9, pp. 116-129.

[48] Virtual Museums (2019), Google Cultural Institute. Available: http://zillion.net/ru/blog/ 264/virtual-nyie-muziei-google-cultural-institute . Accessed on: Mart 01, 2019.

[49] Neshovorova, H. P. (2019). Overview of virtual museums on the Internet. Available: http://www.iis.nsk.su/files/articles/sbor_kas_12_nesgovorova.pdf . Accessed on: Feb. 25, 2019.

[50] Usmanova, A. (2019). Visual research as a research paradigm. Available: http://viscult.ehu.lt/article.php?id=108 . Accessed on: Feb. 25, 2019.

\section{Authors}

Viktoriia Tserklevych is Ph.D. in Education, Associate Professor. She works at the Department of Hotel and Restaurant and Tourism Business, Khmelnytskyi Cooperative Trade and Economic Institute, Khmelnytskyi, Ukraine.

Olha Prokopenko is Doctor of Economics, Professor. She works at Economics Department, Collegium Mazovia Innovative University, Siedlce, Poland, and Teadmus Ltd, Tallinn, Estonia.

Olena Goncharova is Doctor of Cultural Studies, Professor. She works at the Department of Museology and Expertise of Historical and Cultural Values, Kyiv National University of Culture and Arts, Kyiv, Ukraine.

Inna Horbenko is Ph.D. in Education, Associate Professor. She works at the Department of Management, Practical Psychology and Inclusive Education, Hryhorii Skovoroda University in Pereiaslav, Pereiaslav, Ukraine.

Oksana Fedorenko is Ph.D. in Education, Associate Professor. She works at the Department of Special and Inclusive Education, Borys Grinchenko Kyiv University, Kyiv, Ukraine.

Yaroslavna Romanyuk is $\mathrm{PhD}$ in Economics. She works at the Department of International Economic Relations at Sumy State University, Sumy, Ukraine.

Article submitted 2021-03-29. Resubmitted 2021-04-28. Final acceptance 2021-04-28. Final version published as submitted by the authors 